\title{
Depletion of praziquantel in plasma and muscle tissue of cultured rockfish Sebastes schlegeli after oral and bath treatment
}

\author{
Ki Hong Kim ${ }^{1, *}$, Chun Soo Kim¹, Jin-Woo Kim ${ }^{2}$ \\ ${ }^{1}$ Department of Aquatic Life Medicine, College of Fisheries Science, Pukyong National University, Pusan 608-737, Korea \\ ${ }^{2}$ Pathology Division, National Fisheries Research and Development Institute, Pusan 619-900, Korea
}

\begin{abstract}
Depletion of praziquantel in plasma and muscle tissue after oral and bath treatments was studied in cultured rockfish Sebastes schlegeli. In the oral treatment, a single dose of $400 \mathrm{mg}$ praziquantel $\mathrm{kg}^{-1}$ body weight was administered by intubation of the stomach. A bath treatment at $100 \mathrm{ppm}$ of praziquantel for 4 min was also carried out. Plasma and muscle tissue samples were collected at $3,6,12,24,48,72,96,120,144$ and $168 \mathrm{~h}$ post-treatment, and analyzed for praziquantel by reversed-phase HPLC using diazepam as the internal standard. Following oral treatment, praziquantel was detected in plasma and muscle tissue until $96 \mathrm{~h}$ after treatment. In plasma the praziquantel concentration was highest at the $9 \mathrm{~h}$ sampling time and declined sharply at the $48 \mathrm{~h}$ sampling point. The concentrations of praziquantel in the muscle tissue were lower than those in the plasma, and the highest value was found at the $9 \mathrm{~h}$ sampling time. Following bath treatment, praziquantel was found in plasma and muscle tissue until 72 and $24 \mathrm{~h}$ after treatment, respectively. In plasma the praziquantel concentration was highest at the $12 \mathrm{~h}$ sampling time and declined sharply thereafter. The concentrations of praziquantel in the muscle tissue were significantly lower than those in the plasma, and the concentrations declined consistently with time.
\end{abstract}

KEY WORDS: Praziquantel $\cdot$ Depletion $\cdot$ Rerversed-phase HPLC $\cdot$ Plasma $\cdot$ Muscle $\cdot$ Oral and bath treatment

\section{INTRODUCTION}

Praziquantel chemotherapy has been employed to control various internal helminth infections in mammals, and has recently been used to control monogenean diseases in fish by bath treatment (Schmahl \& Melhorn 1985, Moser et al. 1986, Buchmann 1987, Schmahl \& Taraschewski 1987, Schmahl et al. 1989, Buchmann et al. 1990, Szekely \& Molnar 1990, Thoney 1990, Santamarina et al. 1991). Recently, Kim et al. (1998) and Kim \& Cho (2000) reported that oral administration of praziquantel was effective in treating Microcotyle sebastis infestations in cultured rockfish Sebastes schlegeli.

\footnotetext{
*E-mail: khkim@pknu.ac.kr
}

The use of praziquantel in food fish may lead to residues in fish tissues, and the public health authorities require safe drug withdrawal periods. Compared with the wealth of information available on the pharmacokinetics of praziquantel in mammals (Andrews 1976, Leopold et al. 1978, Groll 1984, Bittencourt et al. 1990, Jung et al. 1991, González-Esquivel et al. 1993, Morovján et al. 1998), only few studies have reported on praziquantel in fish.

Concentrations of praziquantel in plasma and tissues of fish were determined by HPLC by Xiao et al. (1983), Rogstad et al. (1987) and Hormázabal \& Yndestad (1995). Björklund \& Bylund (1987) analyzed the pharmacokinetics of praziquantel in rainbow trout Salmo gairdneri by means of a bioassay method using cercariae of Diplostomum spathaceum as test organisms for the drug concentrations. 
The aim of the present study was to determine residues of praziquantel in cultured rockfish after both oral and bath treatments. Praziquantel concentrations were determined by reversed-phase HPLC with UV detection at $217 \mathrm{~nm}$, and diazepam was used as the internal standard.

\section{MATERIALS AND METHODS}

Chemicals and reagents. Praziquantel (2-cyclohexylcarbonyl-4-oxo-1, 2, 3, 6, 7, 11b-hexahydro-4H-pyrazino[2,1-a]isoquinoline) and the internal standard, diazepam (7-chloro-1-methyl-5-phenyl-3H-1,4-benzodiazepin-2[1H]-one), were kindly donated by Shinpoong Pharma. Co. Ltd. (Seoul, Korea). Acetonitrile for the mobile phase and distilled water were of chromatographic grade (E. Merck, Germany). Standard solutions of praziquantel were made by dilution of stock solution with mobile phase (10 $\mu \mathrm{g}$ praziquantel $\mathrm{ml}^{-1}$ mobile phase). The internal standard solution was prepared by dissolving $10 \mu \mathrm{g}$ of diazepam into $1 \mathrm{ml}$ of mobile phase.

Fish. Seventy untreated, clinically healthy rockfish Sebastes schlegeli weighing 150 to $180 \mathrm{~g}$ were obtained from a local rockfish farm. The fish were separated into 2 groups (oral treatment and bath treatment) and were acclimatized for $7 \mathrm{~d}$ before experiments in flow-through 5001 aquaria. The water temperature was 21 to $22^{\circ} \mathrm{C}$ and the $\mathrm{pH}$ was 7.0 to 7.2 . The fish were starved during both the acclimation and the experimental period to avoid differences in drug kinetics owing to differences in nutritional status.

Experimental regimen. Oral treatment: Just before treatment, the fish were anaesthetized with methane sulfonate salt (MS222, $150 \mathrm{mg} \mathrm{l}^{-1}$, Sigma, St. Louis, $\mathrm{MO}, \mathrm{USA}$ ). A single dose of $400 \mathrm{mg}$ praziquantel $\mathrm{kg}^{-1}$ body weight was administered orally by intubation of the stomach. Fish were observed individually for disgorgement until 10 min after drug administration. Control fish received exactly the same treatment as treated fish with the exception of drug application. At $3,6,12,24,48,72,96,120,144$ and $168 \mathrm{~h}$ post-treatment, 3 fish were taken randomly from the aquarium. After anesthesia with MS222, blood was drawn from the caudal vein and a piece of muscle tissue was collected from each fish. Blood samples were centrifuged immediately to obtain plasma. The plasma and muscle tissue samples were kept frozen at $-70^{\circ} \mathrm{C}$ until analyzed. Just before analysis, each muscle tissue sample was defrosted and homogenized.

Bath treatment: Fish were bathed in an aquarium containing a concentration of $100 \mathrm{mg}$ praziquantel $\mathrm{l}^{-1}$ seawater for $4 \mathrm{~min}$. During the treatment the flowthrough system was stopped and the water aerated vigorously to maintain a high oxygen concentration and to prevent the drug from forming a sediment. At 3 , $6,12,24,48,72,96,120,144$ and $168 \mathrm{~h}$ post-treatment, 3 fish were taken randomly from the aquarium. Plasma and muscle samples from each fish were collected as described in oral treatment.

Chromatographic conditions: The instruments used were a Hewlett-Packard (HP1100 Series, USA) HPLC equipped with a QUAT pump (HP1100 Series G1311A), an automatic gradient controller (HP1100 Series G1324A), an injection valve fitted with a $5 \mathrm{ml}$ sampling loop, a variable-wavelength UV detector and a data module. Analysis was performed on an ODS2 C18 column $(125 \times 4 \mathrm{~mm}$, Hewlett Packard) with acetonitrilewater (45:55 v/v) as the mobile phase. The column was kept at room temperature $\left(20\right.$ to $24^{\circ} \mathrm{C}$ ) and the flow
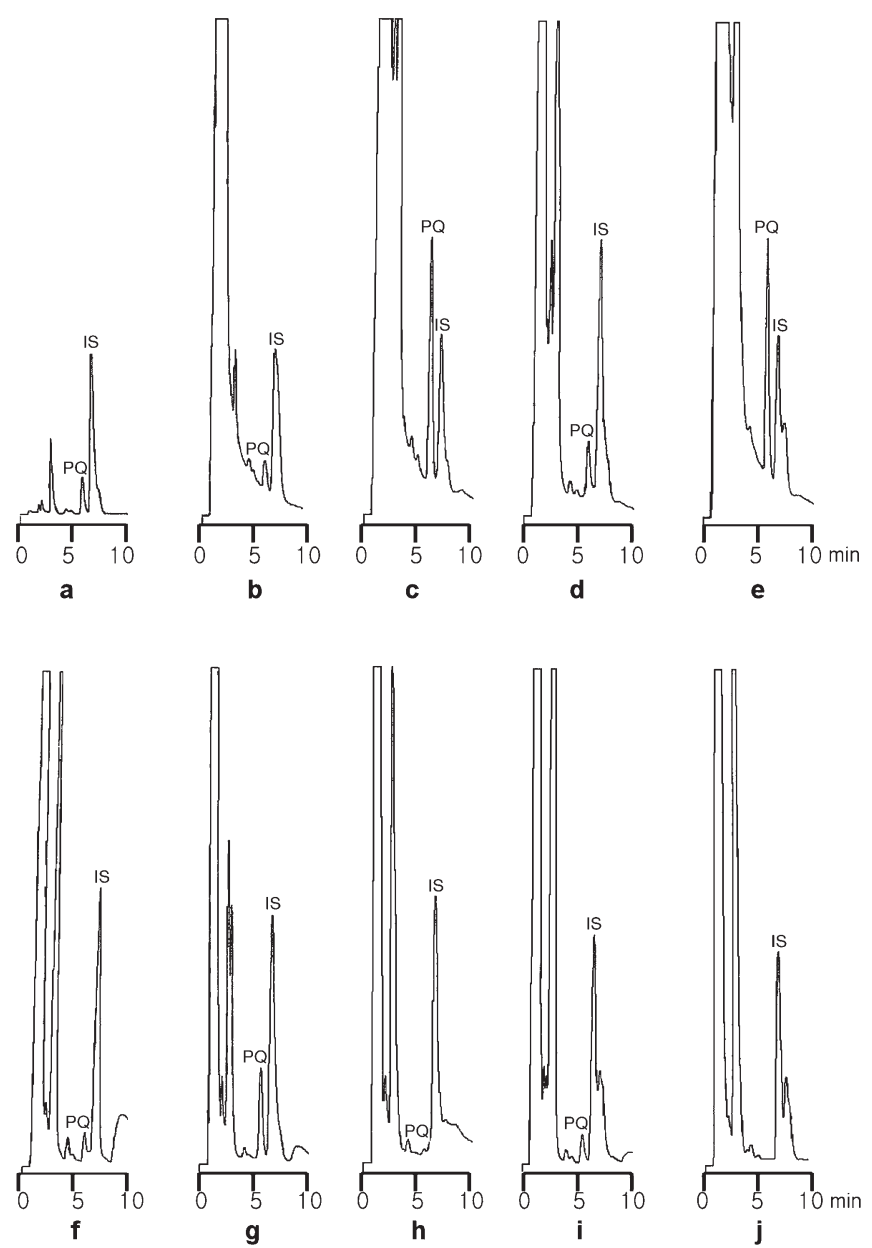

Fig. 1. Chromatograms of praziquantel (PQ) determination in rockfish compared with diazepam as an internal standard (IS). (a) Standard solution of $1 \mu \mathrm{g} \mathrm{m}^{-1}$ of $\mathrm{PQ}_{\text {; }}$ (b) plasma spiked with $1 \mu \mathrm{g} \mathrm{ml}^{-1}$ of $\mathrm{PQ}_{i}$ (c) plasma $9 \mathrm{~h}$ after oral treatment; (d) plasma $48 \mathrm{~h}$ after oral treatment; (e) plasma $12 \mathrm{~h}$ after bath treatment; (f) muscle tissue spiked with $1 \mu \mathrm{g} \mathrm{ml}^{-1}$ of $\mathrm{PQ}_{i}(\mathrm{~g})$ muscle tissue $3 \mathrm{~h}$ after oral treatment; (h) muscle tissue $96 \mathrm{~h}$ after oral treatment; (i) muscle tissue $3 \mathrm{~h}$ after bath treatment; (j) muscle tissue $48 \mathrm{~h}$ after bath treatment 


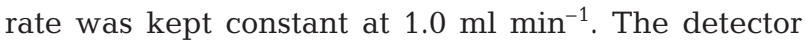
wavelength was set $217 \mathrm{~nm}$. Between each $200 \mu \mathrm{l}$ injection the column was washed for 15 min in plasma or 30 min in muscle tissue with $100 \%$ acetonitrile.

Sample preparation. Plasma: To a $1.0 \mathrm{ml}$ volume of plasma, $1.0 \mathrm{ml}$ of $100 \%$ acetonitrile and $0.4 \mathrm{ml}$ of the internal standard solution were added. The sample was allowed to stand for $10 \mathrm{~min}$ at $4^{\circ} \mathrm{C}$, then, centrifuged at $10000 \times g$ for $10 \mathrm{~min}$. The collected supernatant was evaporated to dryness with a speed vacuum (Heto-Holten A/S, Copenhagen, Denmark). The dry residue was dissolved in $1 \mathrm{ml}$ of mobile phase, and a portion of $200 \mu \mathrm{l}$ was injected into the HPLC.

Muscle tissue: A $2 \mathrm{~g}$ portion of muscle tissue was weighed into a $15 \mathrm{ml}$ corning tube, and $8.6 \mathrm{ml}$ of $100 \%$ acetonitrile was added. The sample was ground using a homogenizer (ART-Moderne Labortechnik, Mülheim, Germany), and then $0.4 \mathrm{ml}$ of internal standard solution was added. After it was allowed to stand for $10 \mathrm{~min}$ at $4^{\circ} \mathrm{C}$, the sample was centrifuged at $10000 \times g$ for $10 \mathrm{~min}$, and the supernatant was collected. The collected supernatant was evaporated to dryness with a speed vacuum. The dry residue was dissolved in $1 \mathrm{ml}$ of mobile phase, and a portion of $200 \mu \mathrm{l}$ was injected into the HPLC.

Calibration curves and recovery rates: Either plasma or muscle tissue homogenate was spiked with standard solutions of praziquantel and internal standard to yield concentrations of $0.25,0.5,1.0,2.0,4.0 \mu \mathrm{g}$ $\mathrm{ml}^{-1}$ praziquantel and $4.0 \mu \mathrm{g} \mathrm{ml} \mathrm{m}^{-1}$ internal standard. Samples were prepared according to the above procedure, and each concentration was assayed in triplicate. The recovery rates were determined by comparing results of the HPLC analysis of the spiked plasma and muscle tissue with those of standard solutions.

\section{RESULTS}

\section{Calibration curve and recovery rate}

Chromatograms of plasma and muscle tissue homogenate are shown in Fig. 1. The retention times for praziquantel and the internal standard were 6.08 and 7.20 min for plasma, and 6.09 and 7.08 min for muscle tissue homogenate, respectively. A linear relation $\left(R^{2}=0.997\right)$ was found when the ratio of the peak height of praziquantel in plasma to that of the internal standard was plotted against the concentration of praziquantel in the range 0.25 to $4.0 \mu \mathrm{g} \mathrm{ml}^{-1}$. A linear relation $\left(\mathrm{R}^{2}=0.990\right)$ was obtained also for the muscle tissue homogenate. The average recoveries of praziquantel, assessed by comparison of peak heights from the biological fluids with those from standard solutions were $99.2 \%$ in plasma and $82.7 \%$ in muscle tissue homogenate (Table 1).
Table 1. Mean recovery of praziquantel in spiked samples of plasma and muscle tissue

\begin{tabular}{|lcc|}
\hline $\begin{array}{l}\text { Amount added } \\
\left(\mu \mathrm{g} \mathrm{m}^{-1}\right)\end{array}$ & \multicolumn{2}{c|}{ Mean recovery $(\%)$} \\
Plasma & Muscle \\
\hline 4.00 & 101.5 & 85.0 \\
2.00 & 99.4 & 69.4 \\
1.00 & 95.4 & 77.8 \\
0.50 & 101.2 & 92.3 \\
0.25 & 98.4 & 88.9 \\
Average $(\%)$ & 99.2 & 82.7 \\
\hline
\end{tabular}

Table 2. Praziquantel in rockfish plasma and muscle tissue samples after oral treatment with the drug at a dosage of $400 \mathrm{mg} \mathrm{kg}^{-1}$ body weight (3 fish per sampling time). Values are mean $\pm \mathrm{SD}$. nd: not detected

\begin{tabular}{|ccc|}
\hline $\begin{array}{c}\text { Sampling time } \\
\text { (hours after treatment) }\end{array}$ & $\begin{array}{c}\text { Plasma } \\
\left(\mu \mathrm{g} \mathrm{ml}^{-1}\right)\end{array}$ & $\begin{array}{c}\text { Muscle } \\
\left(\mu \mathrm{g} \mathrm{g}^{-1}\right)\end{array}$ \\
\hline 3 & $6.69 \pm 1.33$ & $2.49 \pm 0.81$ \\
6 & $7.57 \pm 3.36$ & $3.82 \pm 1.50$ \\
9 & $8.59 \pm 1.83$ & $4.20 \pm 1.59$ \\
12 & $7.11 \pm 0.05$ & $2.51 \pm 1.05$ \\
24 & $8.47 \pm 1.23$ & $3.61 \pm 0.24$ \\
48 & $2.45 \pm 0.92$ & $0.22 \pm 0.10$ \\
72 & $1.88 \pm 0.42$ & $0.08 \pm 0.13$ \\
96 & $1.86 \pm 0.42$ & $0.06 \pm 0.11$ \\
120 & nd & nd \\
144 & nd & nd \\
168 & nd & nd \\
\hline
\end{tabular}

\section{Oral treatment}

The concentrations of praziquantel found in plasma and muscle tissue after oral administration of praziquantel are shown in Table 2, and chromatograms are shown in Fig. 1. Following oral treatment, praziquantel was detected in plasma and muscle tissue until $96 \mathrm{~h}$ after treatment. In plasma the praziquantel concentration was highest at the $9 \mathrm{~h}$ sampling time and had declined sharply at the $48 \mathrm{~h}$ sampling point. The concentrations of praziquantel in the muscle tissue were lower than those in the plasma, and the highest value was found at the $9 \mathrm{~h}$ sampling time.

\section{Bath treatment}

The concentrations of praziquantel found in plasma and muscle tissue after praziquantel bath treatment are shown in Table 3. Following bath treatment, praziquantel was found in plasma and muscle tissue until 72 and $24 \mathrm{~h}$ after treatment, respectively. In plasma the praziquantel concentration was highest at the $12 \mathrm{~h}$ 
Table 3. Praziquantel in rockfish plasma and muscle tissue samples after bath treatment with the drug at $100 \mathrm{ppm}$ for $4 \mathrm{~min}$ (3 fish per sampling time). Values are mean $\pm \mathrm{SD}$. nd: not detected

\begin{tabular}{|ccc|}
\hline $\begin{array}{c}\text { Sampling time } \\
\text { (hours after treatment) }\end{array}$ & $\begin{array}{c}\text { Plasma } \\
\left(\mu \mathrm{g} \mathrm{ml}^{-1}\right)\end{array}$ & $\begin{array}{c}\text { Muscle } \\
\left(\mu \mathrm{g} \mathrm{g}^{-1}\right)\end{array}$ \\
\hline 3 & $4.10 \pm 0.83$ & $0.49 \pm 0.05$ \\
6 & $4.48 \pm 0.78$ & $0.44 \pm 0.13$ \\
9 & $4.06 \pm 0.45$ & $0.30 \pm 0.17$ \\
12 & $5.96 \pm 3.84$ & $0.28 \pm 0.04$ \\
24 & $1.85 \pm 0.11$ & $0.04 \pm 0.07$ \\
48 & $1.25 \pm 0.50$ & nd \\
72 & $0.29 \pm 0.51$ & nd \\
96 & nd & nd \\
120 & nd & nd \\
144 & nd & nd \\
168 & nd & nd \\
\hline
\end{tabular}

sampling time and declined sharply thereafter. The concentrations of praziquantel in the muscle tissue were significantly lower than those in the plasma, and the concentrations declined consistently with time.

\section{DISCUSSION}

Sample preparation and HPLC methods in the present study were fast and simple for the analysis of praziquantel, and showed good recovery of the drug in rockfish plasma and muscle tissue. The recovery of praziquantel in the study of Rogstad et al. (1987) varied from 79 to $93 \%$ for muscle of rainbow trout. In the work of Hormazabal \& Yndestad (1995), the recovery of praziquantel varied from 91 to $92 \%$ for plasma, and from 99 to $100 \%$ for muscle of salmon and rainbow trout.

Although the absorption and depletion of praziquantel in rockfish in this study were slower than those in mammals, the data were similar to those of previous pharmacokinetic studies of praziquantel in rainbow trout (Björklund \& Bylund 1987, Rogstad et al. 1987). In the present study, the residue concentrations of praziquantel in plasma and muscle of rockfish, administered orally at a dose of $400 \mathrm{mg} \mathrm{kg}^{-1}$ body weight, were highest $9 \mathrm{~h}$ after treatment and were eliminated within $120 \mathrm{~h}$ after treatment. According to the preliminary study of Rogstad et al. (1987), the highest residue concentration of praziquantel in muscle and serum of rainbow trout, which were given a single oral dose (10 mg $\mathrm{kg}^{-1}$ body weight) of praziquantel, was obtained $7 \mathrm{~h}$ after treatment, and no residues were found $48 \mathrm{~h}$ after medication. Using a bioassay with parasitic cercariae as test organisms for determination of praziquantel concentrations, Björklund \& Bylund (1987) reported that the peak values of praziquantel in different tissues (serum, muscle, liver, bile fluid, kidney) of rainbow trout were reached 4 to $16 \mathrm{~h}$ after a single oral administration of praziquantel at a dose of $500 \mathrm{mg} \mathrm{kg}^{-1}$ body weight and by $32 \mathrm{~h}$ after administration, 67 to $96 \%$ of the maximum amounts had been eliminated from the tissues.

Considering the sharp decrease in praziquantel concentration in plasma after $24 \mathrm{~h}$ after oral administration in the present study, retreatment at an interval of $24 \mathrm{~h}$ would be effective for eradication of Microcotyle sebastis, a polyopisthocotylean gill parasite of rockfish.

It is known that the gill is the main route of absorption for drugs administered in water (Treves-Brown 2000). However, direct absorption via the skin cannot be excluded. Bathing rockfish with 100 ppm of praziquantel for 4 min in the present study was the same scheme as that used in the treatment of Microcotyle sebastis in field conditions (Kim \& Cho 2000). In the present study, praziquantel residue concentrations in muscle of rockfish after bath treatment were about 10 times lower than those in plasma and showed a consistently decreasing pattern with time. This result suggests that absorption of praziquantel in rockfish following bath treatment is largely through the gills, but a small amount of the drug can be absorbed via skin.

Although the concentrations of praziquantel in plasma after bath treatment were lower than those after oral treatment in the present experimental schemes, not only direct contact of Microcotyle sebastis with praziquantel but also feeding by the parasites on blood containing the drug resulted in high treatment efficacy of $M$. sebastis by bath with praziquantel in the study of Kim \& Cho (2000).

Acknowledgement. This study was supported by a grant from the Ministry of Maritime Affairs and Fisheries, Republic of Korea.

\section{LITERATURE CITED}

Andrews P (1976) Pharmakokinetische Tieruntersuchungen mit Droncit unter Verwendung einer biologischen Prüfmethode. Vet Med Nachr 2:154-165

Bittencourt PRM, Gracia CM, Gorz AM, Oliveira TV (1990) High-dose praziquantel for neurocysticercosis: serum and CSF concentrations. Acta Neurol Scand 82:28-33

Björklund H, Bylund G (1987) Absorption, distribution and excretion of the anthelmintic praziquantel (Droncit) in rainbow trout (Salmo gairdneri R.). Parasitol Res 73: 240-244

Buchmann K (1987) The effects of praziquantel on the monogenean gill parasite Pseudodactylogyrus bini. Acta Vet Scand 28:447-450

Buchmann K, Szekely C, Bjerregaard J (1990) Treatment of Pseudodactylogyrus infestations of Anguilla anguilla II. Trials with bunamidine, praziquantel and levamizole. Bull Eur Assoc Fish Pathol 10:18-20

González-Esquivel DF, Morano OC, Sánchez RM, Sotelo J, Jung H (1993) Sensitive high-performance liquid chromatographic assay for praziquantel in plasma, urine and 
liver homogenates. J Chromatogr 613:174-178

Groll E (1984) Praziquantel. Adv Pharmacol Chemother 20: $219-238$

Hormazábal V, Yndestad M (1995) High-performance liquid chromatographic determination of praziquantel in plasma and tissues of cultured fish for residue and pharmacokinetic studies. J Liq Chromatogr 18:589-597

Jung H, Vazquez ML, Sánchez M, Penagos P, Sotelo J (1991) Clinical pharmacokinetics of praziquantel. Proc West Pharmacol Soc 34:335-340

Kim KH, Cho JB (2000) Treatment of Microcotyle sebastis (Monogenea: Polyopisthocotylea) infestation with praziquantel in an experimental cage simulating commercial rockfish Sebastes schlegeli culture conditions. Dis Aquat Org 40:229-231

Kim KH, Park SI, Jee BY (1998) Efficacy of oral administration of praziquantel and mebendazole against Microcotyle sebastis (Monogenea) infestation of cultured rockfish (Sebastes schlegeli). Fish Pathol 33:467-471

Leopold G, Ungethüm W, Groll E, Diekmann H, Nowak H, Wegner L (1978) Clinical pharmacology in normal volunteers of praziquantel, a new drug against schistosomes and cestodes. Eur J Clin Pharmacol 14:281-291

Morovján G, Csokán P, Makranszki L, Abdellah-Nagy EA, Tóth K (1998) Determination of fenbendazole, praziquantel and pyrantel pamoate in dog plasma by high-performance liquid chromatography. J Chromatogr 797:237-244

Moser M, Sakanari J, Heckmann R (1986) The effects of praziquantel on various larval and adult parasites from freshwater and marine snails and fish. J Parasitol 72:175-176

Editorial responsibility: Wolfgang Körting,

Hannover, Germany
Rogstad A, Hormazabal V, Yndestad M (1987) Extraction of praziquantel from fish tissue and its determination by high-performance liquid chromatography. J Chromatogr 391:328-333

Santamarina MT, Tojo JL, Ubeira FM, Quintero P, Sanmartin ML (1991) Anthelmintic treatment against Gyrodactylus sp. infecting rainbow trout Oncorhynchus mykiss. Dis Aquat Org 10:39-43

Schmahl G, Mehlhorn H (1985) Treatment of fish parasites. 1. Praziquantel effective against Monogenea (Dactylogyrus vastator, Dactylogyrus extensus, Diplozoon paradoxum). Z Parasitenk 71:727-737

Schmahl G, Taraschewski H (1987) Treatment of fish parasites. 2. Effects of praziquantel, niclosamide, levamisole$\mathrm{HCl}$, and metrifonate on Monogenea (Gyrodactylus aculeati, Diplozoon paradoxum). Parasitol Res 73:341-351

Schmahl G, Taraschewski H, Mehlhorn H (1989) Chemotherapy of fish parasites. Parasitol Res 75:503-511

Szekely C, Molnar K (1990) Treatment of Ancylodiscoides vistulensis monogenean infestations of the European catfish (Silurus glanis). Bull Eur Assoc Fish Pathol 10:74-77

Thoney DA (1990) The effects of trichlorfon, praziquantel and copper sulphate on various stages of the monogenean Benedeniella posterocolpa, a skin parasite of the cownose ray, Rhinoptera bonasus (Mitchill). J Fish Dis 13:385-389

Treves-Brown KM (2000) Applied fish pharmacology. Kluwer Academic Publishers, Dordrecht

Xiao S-H, Catto B, Webster L (1983) Quantitative determination of praziquantel in serum by high performance liquid chromatography. J Chromatogr 275:127-132

Submitted: January 11, 2001; Accepted: March 5, 2001 Proofs received from author(s): June 12, 2001 